\section{Estudo Radiológico da Dispersão de Diferentes Volumes de Anestésico Local no Bloqueio de Plexo Braquial pela Via Posterior}

(Rev Bras Anestesiol, 2005;55:508-516)

\section{Sra. Editora,}

Agradeço a oportunidade de acrescentar alguns comentários ao trabalho de Cruvinel e col. ${ }^{1}$. Acidentes anatômicos de percurso podem interferir na distribuição da solução anestésica durante o bloqueio plexular braquial por qualquer abordagem. A anestesia paravertebral não é recente. Em 1912, Max Kappis, cirurgião alemão, entusiasmado pelo feito de seu colega Läwen de ter realizado uma nefrectomia sob bloqueio anestésico paravertebral, expandiu a técnica com novocaína, $5 \mathrm{~mL}$ em cada abordagem ao processo transverso vertebral, para cirurgias do membro superior e região cervical (paravertebral cervical), toracotomias e cirurgias de mama (paravertebral torácica), laparotomias associadas ao bloqueio direto do gânglio celíaco e herniorrafias inguinais (paravertebral abdominal) 2. Quase 80 anos depois, os italianos Pippa e col. ${ }^{3}$ re-introduziram a prática do bloqueio paravertebral cervical de Kappis ao arsenal da anestesia regional sobre o plexo braquial. $\mathrm{Na}$ realidade, a denominação mais apropriada deveria ser bloqueio braquial interescalênico por via posterior 4 . Não apenas a técnica de administração como também variados volumes anestésicos têm apresentado diversos resultados. Isto pode ser depreendido do trabalho de Cruvinel e col. 1 em que administrando por cateter um volume de $10 \mathrm{~mL}$ de anestésico e contraste (Figura 5), este último mimetizou uma distribuição plexular mais abrangente do que com um volume de $30 \mathrm{~mL}$ (Figura 2) por injeção única, provando que a injeção via cateter proporciona uma dispersão de melhor qualidade com menor volume. Já com volumes únicos variando entre $20 \mathrm{~mL}$ e $40 \mathrm{~mL}$, a diferença de dispersão apresentou variações mínimas. Outro dado importante deste tipo de bloqueio é a inconstância de atingir o nervo ulnar $\left[\left(\mathrm{C}_{7}\right), \mathrm{C}_{8}, \mathrm{~T}_{1}\right]$. Aliás, este fato é apanágio especialmente das abordagens supra-claviculares por qualquer via onde o contribuinte $\mathrm{T}_{1}$ não é eficazmente anestesiado, respectivamente em $40 \%{ }^{1}$ e $32 \%{ }^{5}$ dos casos.

Atenciosamente,

Karl Otto Geier

\section{Réplica}

Prezada editora, agradecemos o interesse demonstrado pelo Dr. Geier pelo nosso trabalho. Acreditamos que as contribuições por ele realizadas são extremamente relevantes. Também nos parece mais correta a denominação de bloqueio do plexo braquial interescalênico via poste- rior, embora denominações como bloqueio do plexo braquial por via posterior ou bloqueio paravertebral cervical também estejam corretas. A observação do Dr. Geier a cerca da dispersão do anestésico local é correta para os casos citados. Se há repetição sistemática desse padrão, nós não podemos afirmar baseado no trabalho realizado. A confirmação dessa assertiva deverá ser objeto de estudos subseqüentes.

Atenciosamente,

Marcos Guilherme Cunha Cruvinel, TSA

Carlos Henrique Viana de Castro, TSA

Yerkes P. Silva

Flávio Lago

Flávio França

\section{Radiological Evaluation of the Spread of Different Local Anesthetic Volumes during Posterior Brachial Plexus Block}

(Rev Bras Anestesiol, 2005;55:508-515).

Mrs. Editor

I thank you the opportunity to add some comments to the work of Cruvinel et al. 1. Unforeseen anatomical accidents may interfere in the distribution of the anesthetic solution during the brachial plexus block by any approach. The paravertebral anesthesia is not recent. In 1912, Max Kappis, German surgeon, excited due to his colleague Läwen accomplishment of having carried out a nephrectomy under paravertebral anesthetic blockade, expanded the technique with Novocain, $5 \mathrm{~mL}$ in each approach to the vertebral transverse process, for surgeries in the superior member and cervical area (cervical paravertebral), toracotomies and breast surgeries (thoracic paravertebral), laparotomies associated to the direct blockade of the celiac ganglion and inguinal herniorraphies (abdominal paravertebral) ${ }^{2}$. Almost 80 years later, the Italians Pippa et al. 3 have reintroduced the practice of the cervical paravertebral block of Kappis to the arsenal of the regional anesthesia on the brachial plexus. In fact, the most appropriate denomination should be brachial interescalenic block by posterior pathway ${ }^{4}$. Not only the administration technique, as well as different anesthetic volumes have been presenting several results. This can be inferred from the work of Cruvinel et al. ${ }^{1}$, in which administering by means of a catheter a volume of $10 \mathrm{~mL}$ of anesthetic and contrast (Figure 5), the latter mimetized a more comprehensive plexular distribution than with a volume of $30 \mathrm{~mL}$ (Figure 2) per a single injection, proving that the injection through the catheter provides a better quality dispersion with smaller volume. While with single volumes varying between $20 \mathrm{~mL}$ and $40 \mathrm{~mL}$, the dispersion difference presented minimal variations. Another important data of this kind of blockade is the inconstancy of reaching 
the ulnar nerve $\left[\left(\mathrm{C}_{7}\right), \mathrm{C}_{8}, \mathrm{~T}_{1}\right]$. Moreover, this fact is apanage especially of the supraclavicular approaches by any pathway where T1 contributor is not efficaciously anesthetized, respectively in $40 \% 1$ and $32 \% 5$ of cases.

Yours sincerely,

Karl Otto Geier, M.D.

\section{Reply}

Dear editor, we thanked the interest demonstrated by M.D. Geier to our work. We believe that the contributions accomplished by him are extremely relevant. In our point of view, the designation of interscalenic brachial plexus block by posterior pathways seems more correct, although denominations as brachial plexus block by posterior pathway or cervical paravertebral block are also correct. M.D. Geier's comment on the dispersion of local anesthetic is correct for the cases mentioned. If there is systematic repetition of this pattern, we cannot affirm based on the work carried out. The confirmation of this assertive must be object of subsequent studies.

Yours sincerely,

Marcos Guilherme Cunha Cruvinel, TSA, M.D.

Carlos Henrique Viana de Castro, TSA, M.D.

Yerkes P. Silva, M.D.

Flávio Lago, M.D.

Flávio França, M.D.

\section{REFERÊNCIAS - REFERENCES}

01. Cruvinel MGC, Castro CHV, Silva YP et al - Estudo radiológico da dispersão de diferentes volumes de anestésico local no bloqueio de plexo branquial pela via posterior. Rev Bras Anestesiol, 2005;55:508-516.

02. Kappis $\mathrm{M}$ - Ueber leitungsanästhesie an bauch, brust, arm und hals durch injektion aus foramen intervertebrale. Muenchener Medizinische Wochenschrift 1912;15:794-796.

03. Pippa P, Cominelli E, Marinelli $C$ et al - Brachial plexus block using the posterior approach. Eur J Anaesthesiol, 1990;7:411-420

04. Dagli G, Guzeldemir ME, Acar HV - The effects and side effects of interscalene brachial plexus block by posterior approach. Reg Anesth Pain Med, 1998;23:87-91.

05. Sandefo I, Iohom G, Elstraete AV et al - Clinical efficacy of the brachial plexus block via the posterior approach. Reg Anesth Pain Med, 2005;30:238-242. 